\title{
Foreign Liquidity, Economic Openning and Growth in Latin American Economies*
}

\author{
Márcio Holland ${ }^{* *}$ \\ Flávio Vilela Vieira ${ }^{* * *}$
}

Summary: 1. Introduction; 2. Financial opening and growth: theory and empirics; 3 . Variable description and econometric model; 4. Empirical findings; 5. Final considerations.

Keywords: Foreign liquidity; trade opening; economic growth; Latin America.

JEL Codes: F41; F43; C23.

The main concern of our empirical study is to shed light on the question of whether or not and in which direction long-term growth has been associated with financial (liquidity) and trade opening since early the 1970s using a panel data approach for 11 Latin American countries. Previous empirical studies reported mixed results in terms of finding a stable association between capital account liberalization and growth or even for trade opening and growth. Our empirical results suggest an important link between international liquidity and growth, but the same does not apply for trade opening and growth.

O propósito central deste estudo empírico é discutir as relações entre o crescimento econômico de longo prazo e a liquidez externa, assim como deste com a abertura comercial, desde começo dos anos 70, usando a abordagem de painel para onze economias da América Latina. Estudos anteriores encontraram resultados controversos em termos da existência de relações estáveis entre a liberalização da conta de capital e o crescimento econômico, ou ainda, entre a abertura comercial e o crescimento de longo prazo do PIB. Nossos resultados empíricos sugerem um importante vínculo entre a liquidez externa e crescimento, mas o mesmo não pode ser observado para a relação entre abertura comercial e crescimento econômico.

\footnotetext{
${ }^{*}$ This paper was received in Oct. 2003 and approved in Nov. 2004. We would like to thank the anonymous referee for many helpful suggestions. This paper had been supported by CNPq and CAPES.

** Institute of Economics at Federal University of Uberlândia, CNPq Researcher and Visiting Scholar at University of California, Berkeley, USA. E-mail: mholland@ufu.br

${ }^{* * *}$ Institute of Economics at Federal University of Uberlândia and CNPq Researcher. E-mail: flaviovieira@ufu.br
} 


\section{Introduction}

The main concern of our empirical study is to shed light on question of whether or not and in which direction long-term growth has been associated with financial (liquidity) and trade opening since early the 1970s using a panel data approach for 11 Latin America countries. It is well known from literature that more recently, developing countries have faced periods of international financial crises with significant outcomes, which are generally associated with lower economic growth rates for the last two decades when compared to historical rates during the sixties and seventies. Given the fact that most developing and emerging economies have gone through a period of opening trade and capital accounts since early the 1990s we want to investigate if and how different measures of liquidity (three) and trade flows can be part of the explanation for long-term economic growth in Latin American economics.

It is fair to relate trade and financial opening and economic growth in the sense that the first one is characterized by an increase in trade of goods while the second in trade of capital since foreign investment can be considered a kind of intertemporal trade, and based on the argument that trade benefits economic growth, one can argue that higher capital mobility will have similar impact on growth. The implications of this line of argument is in the background of our research where we will be using a panel data for Latin American economies to investigate possible implications of changes in international liquidity and trade opening to long-term growth. One has to remember that international liquidity is generally associated with capital account liberalization in the sense that without the latter (no capital mobility) international financial markets have a limited role to be played in fostering higher economic growth rates.

The paper is divided in three sections other than this one and final considerations. Section two develops an overview of the literature on financial opening and growth, section three deals with some methodological issues related to panel data analysis and variable description, and section four summarizes the main empirical findings. We can draw a general conclusion from the present work, suggesting no clear link between trade openness and growth, even though there is evidence that high international liquidity and an improvement in long-term growth rates are positively associated with Latin American economies. 


\section{Financial Opening and Growth: Theory and Empirics}

The main task of this section is to summarize what theory says regarding the relationship between financial opening and growth, and analyze the empirical findings associated with this issue.

One can say that theory has no unambiguous prediction of whether or not capital account liberalization enhances growth, while the empirical evidence can be considered inconclusive to some extent. At a first sight, there are two channels through which capital account liberalization affects growth. The first one is associated with the argument that higher capital mobility increases the domestic investment rate since capital flows towards countries where capital is relatively scarce and the marginal productivity of capital is higher, and the outcome is higher economic growth rates. A second possible channel is expressed by a situation where capital flows to investments with higher rates of return (portfolio diversification) when financial markets do not operate with significant distortions and the impact of capital account liberalization is generally associated with a more efficient resource allocation and a faster rate of economic growth. ${ }^{1}$ Based on the recent past experience of Latin American countries it should be emphasized that the second channel might be insignificant or even negative in affecting growth rates when we take into account transaction costs and the higher volatility of capital flows to the region.

The predictions offered by theories regarding the international financial integration effects on growth can be considered conflicting to some extent. International financial integration facilitates risk-sharing (diversification), which enhances capital allocation and economic growth, but it can have a negative impact on growth if it is implemented under economic conditions where the existence of distortions is the rule rather than the exception. ${ }^{2}$ The policy prescription to extend

\footnotetext{
${ }^{1}$ The outcome is conditioned on how domestic and international financial markets operate, where financial instability can be harmful to achieve higher economic growth rates. Obstfeld (1994) is a pioneer work linking financial openness and growth in a model with portfolio diversification. Barro et al. (1995) developed an open economy version of a neoclassical growth model where the constraint that domestic savings is the only source to finance domestic investment, and in this situation, capital account liberalization (increase in the access to foreign savings) will increase capital accumulation and the economy can achieve higher economic growth rates.

${ }^{2}$ Other possible beneficial effects of international financial integration on growth are associated with the improvement of the domestic financial system (higher competition and new financial services imported). Trade distortions may result in a process of capital account liberalization where capital flows to sectors with no comparative advantage with unfavorable economic growth outcomes.
} 
the process of financial integration in less-developed countries is controversial. ${ }^{3}$

A significant number of empirical studies on capital account liberalization and growth have been recently developed and the remainder of this section will briefly survey the most important empirical results suggested by the literature. ${ }^{4}$

Recent studies on capital account liberalization and growth have not find supportive results. Grilli and Milesi-Ferretti (1995) found that financial opening has small and insignificant effects on growth. Rodrik (1998) used a similar approach for a larger sample and found no stable association between capital account liberalization and growth. According to Kraay (1998) there is no link between economic growth and the International Monetary Fund's restriction measure.

On the other hand, Quinn (1997) developed an empirical analysis considering the impact on economic growth of both capital account openness and the change in openness where the results suggest a positive association between the change in capital account openness and growth. ${ }^{5}$ Edwards (2001) found a significant positive effect of capital account liberalization on growth, but the results were restricted to high-income countries. ${ }^{6}$ Klein and Olivei (1999) found a positive effect of capital account liberalization on growth for industrial countries, but not for less-developed countries. Arteta et al. (2001) when introducing proxies for the degree of macroeconomic stability highlight the existence of some support for differences in the effect of capital account liberalization across countries. ${ }^{7}$

Among the studies on capital account liberalization and growth including some measure of trade openness as an additional (control) variable we can mention Eichengreen and Leblang (2002) and they found a positive and significant coeffi-

\footnotetext{
${ }^{3}$ See Rodrik (1998) for the argument and empirical evidence that capital account liberalization cannot be positively associated to higher economic growth rates.

${ }^{4}$ See table A.1 of the Appendix for an overview of the empirical studies on financial opening and growth where we compare each one of them in terms of number of countries studied, period of investigation, variables used, estimation technique and main results.

${ }^{5}$ The empirical study developed by Quinn (1997) suggest that the change in capital account liberalization has a strong significant effect on the growth in real per capita GDP but he does not include a regression with both of these indicators (financial and trade openness). One has to remind that changes in financial openness is correlated with changes in trade openness, where the finding of a significant effect of the change in capital account liberalization on growth may reflect the correlation of changes in restrictions on the capital account and the current account.

${ }^{6}$ Different results were found by Edison et al. (2002) where the association of capital account liberalization with growth is stronger in less developed countries, while Arteta et al. (2001) found evidence that neither for developed or developing countries capital account liberalization affects growth.

${ }^{7}$ Sachs and Warner (1995) introduced openness index and the exchange black market premium. The results indicate that countries that open their capital accounts grow faster only if they eliminate the black market premium.
} 
cient for the impact of trade opening on growth. ${ }^{8}$ Another empirical research on international financial liberalization and growth that includes trade openness as a control variable is McLean and Shrestha (2002) where the coefficient showed up as positive and significant regardless whether the sample includes both developed and developing countries or only the latter. Arteta et al. (2001) used the Sachs-Warner trade openness measure and the coefficient is positive and significant for a pooled regression. ${ }^{9}$ Klein and Olivei (1999) examine the impact of financial development on growth including a vector of control variables that are potentially related to each country's economic growth, where one of them is the 1986 ratio of exports plus imports to GDP and the results do not change by the inclusion of such a variable (open capital account increases financial depth and higher economic growth rates). Levine et al. (1999) developed a dynamic panel estimation with two sets of conditional information where in one of them openness to trade (log) is used and the results suggested a positive and significant effect for financial intermediation and growth.

Since we are including openness to trade defined as the ratio of the sum of exports and imports relative to GDP as one of our variables to capture possible impacts on long-term growth in Latin America, it is necessary to develop a brief description on how the literature and empirical research has seen this relationship. The literature on openness to trade and growth has been characterized by controversies in terms of associating openness with higher growth rates. Rodriguez and Rodrik (2001) is one of the empirical works that did not find such positive association in the sense that liberal trade policies did not guarantee faster growth rates. On the other hand, different empirical studies found that lower trade barriers together with a stable exchange rate system, sound monetary and fiscal policies help promoting economic growth. ${ }^{10}$

After reviewing the most important empirical results on capital account liberalization and growth it is clear that there is no consensus. Trying to understand such disparity we can argue that not only the econometric techniques and estimation methods are different but also the span of data and countries studied are not homogeneous. Other than this, the use of different measures of capital account liberalization might be capturing different aspects of how changes in capital flows can affect growth rates. One example is when measuring capital account liberalization based only on restrictions (legal issues) to capital flows without taking into

\footnotetext{
${ }^{8}$ The results apply for 47 countries during the period of 1975-95.

${ }^{9}$ The same result has not been derived when including a different measure of trade openness based on the interaction between the Barro-Lee trade measure and Quinn's measure of capital account liberalization. The coefficients are positive but not significant.

${ }^{10}$ See Baldwin (2003) for a survey of the literature on openness and growth.
} 
account the specificities of the domestic money (credit) market since we expect the latter to have a significant impact on growth. Finally, the use of different control variables might be part of the explanation of these different results in the sense that including or not variables such as inflation, government size, openness to trade, among others will capture important nuances of how capital account liberalization is linked (or not) to growth rates. ${ }^{11}$

\section{Variable Description and Econometric Model}

The main model to be estimated and the variables description are the following:

$$
\vec{y}_{i t}=\alpha_{i}+\beta_{0} \text { Open }_{i t}+\beta_{1} F L 01_{i t}+\beta_{2} F L 02_{i t}+\beta_{3} F L 03_{i t}+\beta_{4} y_{i t}+\epsilon_{i t}
$$

where $\vec{y}_{i t}$ is the real GDP growth rate; $O p e n_{i t}$ is the trade opening; $F L_{i t}$ is the foreign liquidity measured according to $F L 01$ (the ratio between the foreign reserves and the imports), FL02 (the ratio of external debt to real GDP), FL03 (the ratio external debt and exports), and $y_{i t}$ is the real GDP. We are expecting a positive coefficient of $\beta_{1}$ and a negative coefficient of $\beta_{2}$ and $\beta_{3}$. A positive coefficient should be associated with the idea that more liquidity improves growth, while for a negative one a higher liquidity indicator deteriorates growth. The data for the empirical estimation is from the International Financial Statistics (International Monetary Fund) and the World Development Indicators (World Bank).

The estimation of equation (1) has been implemented using the original sample with annual data from 1972 to 2000, averaging the data for each five years, except for the first observation (1972-1975). The correlation matrix from table A.3 suggests that there are similar mean samples and dispersion measures, and the same applies for the correlation between the variables used in the empirical research. We used the transformed mean sample to estimate model (1).

Estimation using panel data has several advantages over purely cross-sectional estimation. First, besides considering the cross-country relationship between financial development (international liquidity) and growth, we also would like to take into account how financial development over time within a country may have an impact on growth performance. A panel analysis helps in terms of having higher degrees of freedom by adding the variability of the time-series dimension to the analysis. It is also true that in a panel context, we are able to control for

\footnotetext{
${ }^{11}$ See table A.1 of the appendix for a general overview of the empirical findings.
} 
unobserved country-specific effects and thereby reduce possible bias in the estimated coefficients. Our panel estimator controls for the potential endogeneity of all explanatory variables, while the cross-section estimator used in previous studies only controls for the endogeneity of financial development. The way our panel estimator controls for endogeneity is by using "internal instruments", that is, instruments based on lagged values of the explanatory variables. This method does not allow us to control for full but only for weak endogeneity. ${ }^{12}$

The panel approach allows for two basic models: fixed and random effect models, both of them accepting static and dynamic specifications. The fixed effect model, also known as least square dummy variable (LSDV), is a generalization of an intercept-slope-constant model for panel analysis, introducing a dummy variable to capture the effects of omitted variables that are constant over time.

In this specification, the individual-effects can be freely correlated with the regressors. Their estimation is, in fact, the own estimation of the model of multiple regressions with binary variables for each one of the $n$ units of the analysis, in such a way that their introduction will cause the intercept of the regression to be different for each one of these variables and pick up the heterogeneity among them. The ordinary least square (OLS) estimator will be consistent and efficient, known as LSDV.

The random-effect model specification considers the individual-specific effects as random variables, assuming no correlation between the individual effects and the other random variables, where the estimation was pursued using the Generalized Least Square (GLS).

One crucial question is to know which is the most appropriate model? According to Frees (2003) it depends on the available information and the estimation goals. If, for example, the main concern of the analysis will be to test the effect of the variables where the individuals are classified in groups, then the random effect specification is more appropriate. In Hsiao (1999:42): "The fixed-effects model is viewed as one in which investigators make inferences conditional on the effects that are in the sample. The random-effects model is considered as the one

\footnotetext{
${ }^{12}$ To be precise, Levine et al. (1999) assumed that the explanatory variables are only "weakly exogenous", which means that they can be affected by current and past realizations of the growth rate, which must be uncorrelated with future realizations of the error term. Thus, the weak exogeneity assumption implies that future innovations of the growth rate do not affect current financial development. This assumption is not particularly stringent conceptually and we can examine if it is statistically valid. Weak exogeneity does not mean that economic agents do not take into account expected future growth in their decision to develop the financial system; it just means that future (unanticipated) shocks to growth do not influence current financial development. It is the innovation in growth that must not affect financial development.
} 
in which one can make unconditional or marginal inferences with respect to the population of all effect."

A static panel-data model can be written as:

$$
y_{i t}=x_{i t}^{\prime} \beta+\lambda_{t}+\eta_{i}+\epsilon_{i t} \quad t=1, \ldots, T \quad i=1, \ldots, N
$$

where $\lambda$ and $\eta_{i}$ are time and individual specific effects respectively, $x_{i t}$ is a vector of explanatory variables, $N$ is the number of cross-section observations and $N T$ is the total number of observations.

The main goal is to obtain a consistent estimator of $\beta$ with the desired efficiency proprieties. The choice of the estimation technique to be used depends on the hypothesis assumed for the relationship between the error-term $\left(\epsilon_{i t}\right)$ and the regressors $\left(x_{i t}\right)$ in terms of random error and the fixed effect $\eta_{i}$. In the more restrictive case, one can assume that $E\left(\eta_{i}, x_{i t}\right)=0$ (the orthogonality between the fixed-effect and the regressors) and $E\left(\epsilon_{i t}, x_{i t-s}\right)=0$ for any number of lags $(s)$.

One can use OLS or LSDV since both provide consistent estimators, but the second is more efficient. If we do not consider the hypothesis of orthogonality between the fixed effect and the regressors, that is, if we assume $E\left(\alpha_{i}, x_{i t}\right) \neq 0$, it is not possible to assume consistency for the OLS estimation, and LSDV should be the estimation choice. Another consistent estimator is OLS using the first difference (FD-OLS), ${ }^{13}$ but some caution is necessary due to possible non-efficiency problems.

One can also assume that $E\left(\alpha_{i}, x_{i t}\right)=0$. In this case, none of the above estimators (OLS, LSDV or FD-OLS) are consistent, and to obtain consistent estimators of $\beta$ we need to use Instrumental Variables (IV) or GMM (Generalized Methods of Moments).

Considering the model represented by equation (2) if $\alpha_{i}$ is not assumed to have fixed parameters, we are dealing with a Random Effect Model, and in this case we assume that $\alpha_{i}$ are identically and independently distributed with zero mean and variance $\sigma_{\alpha}^{2}$ and $\left\{\alpha_{i}\right\}$ are independent variables with random errors $\left\{\epsilon_{i t}\right\}$.

Comparing the estimated slopes for the fixed and the random effect models, one can say that: 1) assuming that the formulation of the fixed effects is right, so $\beta_{F E}$ is consistent and asymptotically efficient, and $\beta_{R E}$ is inconsistent. 2) assuming that the formulation in terms of random effect is right, $\beta_{R E}$ is consistent and asymptotically efficient, and $\beta_{F E}$ is consistent, as well.

According to Hsaio (1999:36), the GLS estimator is the weighted average between-groups and within-groups. In the LSDV procedure (fixed effect model)

\footnotetext{
${ }^{13}$ Taking the first difference in (1), the fixed effect is eliminated.
} 
the source of variation is not taken into account and OLS and LSDV can be considered as an example of all or nothing in terms of variation between groups. The procedure that considers $\alpha_{i}$ as random allows for an intermediate solution and does not have to treat everyone as different or similar, according to GLS estimators.

In models (1) and (2), there are no lagged variables, nether regressors or explanatory variables. Incorporating such elements, we suggest the following model:

$$
y_{i t}=\alpha_{i}+\rho y_{i t-1}+\beta x_{i t}+\lambda_{t}+\epsilon i t \quad \text { for } i=1, \ldots, N \text { and } t=1, \ldots, T
$$

where $E \epsilon_{i t}=0, E \epsilon_{i t} \epsilon_{i j}$ for $i=j$ and $t=s$, and $E \epsilon i t \epsilon_{i j}$, for all the other cases.

If we assume $E\left(\alpha_{i}, x_{i t-s}\right)=E\left(\epsilon_{i t}, x_{i t-s}\right)=0$, to $s \neq t$, then the $\beta$ parameters can be estimated in a consistent way using any methods suggested so far. However, it is not possible to estimate a consistent parameter, and the idea is to use instrumental variables to get consistency. One possibility is to use the variables $\Delta y_{t-j}$ and $y_{i t-j},{ }^{14}$ where the following property will be fulfilled:

$$
\begin{aligned}
& E\left[\left(\Delta y_{i t}-\rho \Delta Y_{i t-1}-\beta_{1} \Delta x_{i t}-\beta_{2} \Delta x_{i t-1}\right) y_{i t-j}\right]= \\
& E\left[\left(\Delta y_{i t}-\rho \Delta Y_{i t-1}-\beta_{1} \Delta x_{i t}-\beta_{2} \Delta x_{i t-1}\right) y_{i t-j}\right]=0 \\
& \text { for }(j=2, \ldots, t-1 ; t=2, \ldots, T)
\end{aligned}
$$

If $E\left(x_{i t-s} \epsilon_{i}\right) \neq 0$ and $E\left(\alpha_{i}, x_{i t}\right) \neq 0 s \neq t$, OLS and LSDV do not provide consistent estimations of $\beta$. We have to use the regressors in first difference and instruments for $\Delta x_{t}$ and $\Delta x_{t-1}$, where a good example will be $x_{i t-2}$ or $\Delta x_{t-2}$, following the suggestion from Anderson and Hsiao (1982).

Arellano and Bond (1991) suggest an alternative approach using GMM based on equation (3):

$$
\Delta y_{i t}=\rho \Delta y_{i t-1}+\beta_{1} \Delta x_{i t}+\beta_{2} \Delta x_{i t-1}+\epsilon_{i t}-\epsilon_{i t-1}
$$

There are two basic differences between equations (3) and (4): a) the fixed effect, $\alpha_{i}$, presented in (3) was eliminated in (4) by differentiation and; b) first order autocorrelation was introduced in (4). Even though the estimator HD (Anderson and Hsaio proposition) allows one to obtain consistent estimators, it does not have the desired efficiency property. Efficiency is not present due to autocorrelation in

\footnotetext{
${ }^{14}$ Anderson and Hsiao (1982) suggested these estimators. See Arellano and Bond (1991:278).
} 
the disturbance terms and the eventual presence of heteroskedasticity would result in efficiency problems. ${ }^{15}$

As we know, estimation using panel data (pooled cross-section and time-series data) allows us to exploit the time-series nature of the relationship between liquidity and trade opening with respect to growth. It is important to mention that in a pure cross-country instrumental variable (IV) regression, as in most initial empirical studies, any unobserved country-specific effect becomes part of the error term, bringing up a problem of bias in the coefficient estimates. On the other hand, the dynamic panel approach offers some advantages when compared to OLS estimation, where the empirical results has shown some improvement on previous efforts to examine the link between international financial integration and growth.

\section{Empirical Findings}

At first glance, it is important to highlight similar features observed among Latin American economies. Fluctuation in economic growth over time since the 1970s has been associated with an increase in the degree of trade opening and in foreign liquidity, regardless of the indicator examined. But we need to know whether experiences of high economic growth are followed by higher foreign liquidity and degree of trade openness. Although we are studying a large number of emerging countries, it should be mentioned that there are many differences among them over the period considered. We can see that Chile has grown at increasing rates, has high trade opening and faced increasing international liquidity. On the other hand, we have economies like Brazil where for each decade the growth rate has been lower than the secular one, the degree of trade openness is low, but faces an increasing international liquidity throughout the past decades. Mexico can be considered as an intermediate case showing a sustainable long term economic

\footnotetext{
${ }^{15}$ Arellano and Bond (1991) suggest Hausman and Sargan tests to analyze whether or not equation (3) specification is the right choice. Sargan $(1958,1983)$ proposed a test of overestimation where the idea is to verify if the instruments used are orthogonal to estimated residuals. The Hausman test on coefficients of lagged variables can be implemented in a sequential way. In this case, first lag is not a valid instrument since it will generate correlation between the variable and the residual, such as the estimation using GMM where only in this condition the estimation will be inconsistent. When the null hypothesis is rejected, it is an evidence of first order autocorrelation. Then, for the statistic of Hausman test, our null hypothesis is that the fixed effect model is the right one and the alternative hypothesis is that the random effect model is the right. The statistic $\beta_{E F}-\beta_{R E}$ tends to zero under the null and to some different value from zero under the alternative. More specifically, under $H o$, the Hausman statistic is: $H S=\left(\beta_{F E}-\beta_{R E}\right)^{\prime}\left(\operatorname{Var}\left(\beta_{F E}-\beta_{R E}\right)^{-1} \beta_{F E}-\beta_{R E}\right.$ with $X^{2}$ distribution with $K$ degrees of freedom.
} 
growth, a strong process of trade opening and high foreign liquidity. Regarding the other economies, there are unclear signs in terms of trade opening or even when we try to take into account the role of liquidity relating to economic growth. As a general rule, we can say that each Latin American country has experienced an increase in international liquidity during the last decade when compared to historical levels, even though economic growth rates have not followed the same path for most of them. ${ }^{16}$

A second feature to be highlighted is that the degree of trade opening averages around $26 \%$, with a high dispersion within the region, with a coefficient of variation near $80 \%$. On the other hand, the international liquidity indicators have increased throughout the last decades but with a high disparity among countries. Based on this, one issue that comes to mind and should be pointed out is the existence of a structural heterogeneity in many dimensions of the analysis, as we can see in table A.3, with differences in terms of economy size, real GDP variation coefficient (143\%), international liquidity (Bolivia, Ecuador and Paraguay for low levels), trade opening (Chile, Bolivia, Ecuador, Venezuela and Mexico with higher than average index). It is difficult to say that economies with lower GDP levels have lower degree of trade opening, especially when considering Brazil, which is the largest economy of the region, but it is fair to say that economies with higher GDP levels face a higher degree of foreign liquidity, with some variation over time.

We estimate model (1) using different methods of analysis, including the fixed effect and random effects models, both for static and dynamic approaches. In a panel data setting we have time-series observations for multiple economies and the time-series observations cover the same period, which is denominated a balanced panel.

Our static panel data estimators were obtained by OLS in levels, by GLS (OLS residuals) and by Maximum Likelihood (ML), where the dynamic panel data estimators were obtained using ML one step GMM (Generalized Methods of Moments) estimation. The fixed effect model was estimated by LSDV (Least Square Dummy Variable). The first Wald test for the significance on all variables except the dummy (which is the constant term), is the $\xi^{2}$ equivalent to the overall F-test. The next Wald test reports the significance of the constant term, and it is just the square of the t-value. The $\operatorname{AR}(1)$ test for first order serial correlation, which is significant when one variable is considered. And, more generally speaking, the Sargan test deals with over identification of restrictions. Figure 1 shows a crossplot for actual and fitted values, and the residuals for only one estimation that we consider reasonable, that is using ML one-step estimation.

\footnotetext{
${ }^{16}$ Brazil, Ecuador, Colombia and Paraguay are good examples. See table A.2.
} 
Figure 1

Estimated and Fitted Real Economic Growth and Residual from Panel Analysis (ML by 1-Step)

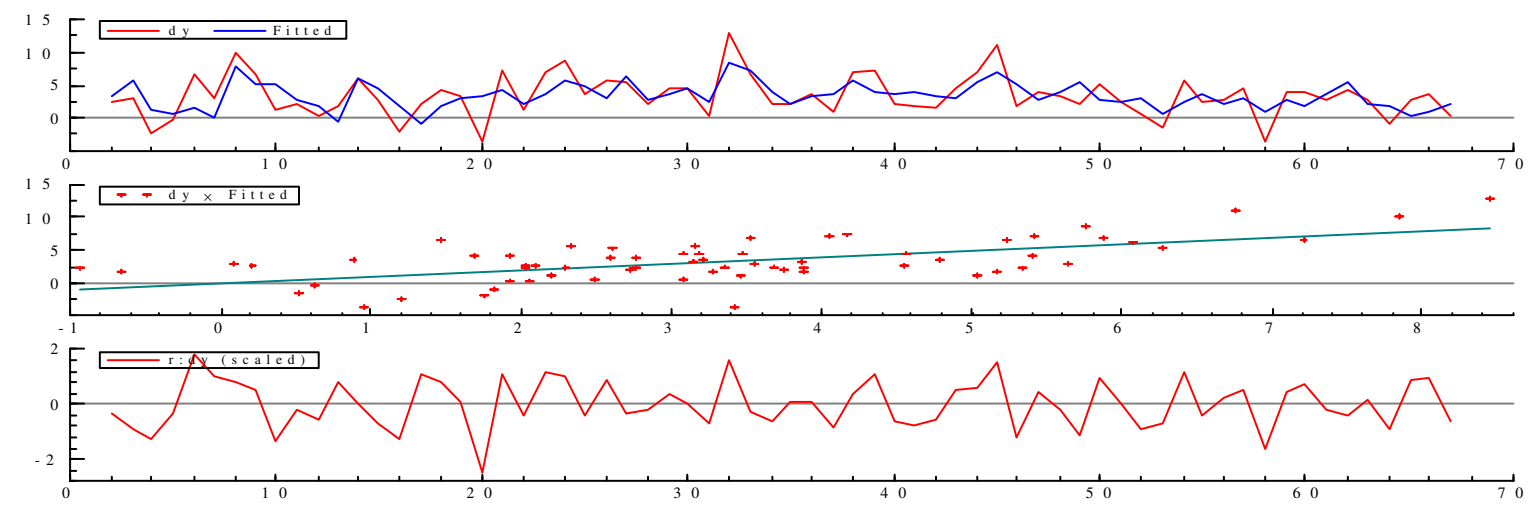

The econometric results from our panel estimation are summarized on table A.5. There are three important lessons to be highlighted. First, observing only the parameter estimation for trade opening it is difficult to conclude that a high degree of trade opening can explain high economic growth for most specifications, except for the OLS (pooled regression) where we found a negative and significant coefficient. All the remaining specifications have shown different coefficients (negative and positive) but all of them are not statistically significant. One should remeber that the OLS estimation (pooled regression) ignores the panel aspect of the data, in other words, the country-specific effect is not captured by the model. In the specification OLS-Diff, we use first differences, removing country-specific effects and the intercept. The least-squares dummy variable (LSDV) estimation reports similar results, except that the coefficients on the country dummies are reported. By using this specification it is difficult to accept the idea that a higher degree of trade opening explains a low real GDP growth rate.

Second, it is fair to conclude that foreign liquidity measured either by the ratio of foreign reserves to imports (FL01) or by external debt to exports (FL03), can explain improvements in real GDP growth rates in Latin American economies, either using the ML one-step estimation or the LSDV estimators for the first proxy of international liquidity. It is important to emphasize that the coefficients have the expected sign (positive for $\beta_{1}$ and negative for $\beta_{2}$ and $\beta_{3}$ ).

Finally, we have an important conclusion regarding country size and the effect on long-term real economic growth. As we have already said, although we are analyzing emerging economies within the same region, there are structural differences among them, especially in terms of country size. On one side we have 
small economies with GDP of approximately US $\$ 7,5$ billions and US $\$ 9,5$ billions (Bolivia and Paraguay, respectively), while on the other we have Brazil with a GDP of US $\$ 700$ billions, not to mention economies with intermediate size like Argentina (GDP around US\$290 billions and Venezuela with US\$80 billions). Taking into consideration such disparities, we introduced the real GDP in the equation for economic growth rate to capture possible country size effects on long-term growth. All coefficients for country size ( $\beta_{4}$ in equation 1$)$ estimated with different econometric techniques have expected signs (negative) but are not statistically significant except for the LSDV cases. This is an indication country size matters and that large economies tend to face lower economic growth rates over a long term.

Once we have analyzed our empirical results for Latin American economies since the early 1970s and after comparing them with the empirical evidence reported in literature and summarized in the first section of the paper, we can say that it is difficult to find a stable association of capital account liberalization and growth, as well as for trade opening and growth. Our empirical results follow the same trend from the literature, but at the same time we could find some evidence linking international liquidity and growth, but not for trade opening and growth.

\section{Final Considerations}

One of the conclusions we can draw from the empirical findings is the difficulty to find a stable relationship associating international liquidity and growth, which is conditioned to the proxy used for foreign liquidity and to the estimation method used for panel data analysis. On the other hand, there is no empirical evidence for a link between trade openness and growth in Latin American countries since 1972. Stronger evidence of a significant association between foreign liquidity and growth was found when we use the concepts of external debt relative to exports, followed by the case when using foreign reserves relative to imports, but the result does not hold when we measure liquidity as the ratio of external debt relative to GDP.

Comparing these results to the other ones in literature, we believe that it is difficult to reject the idea that an increase in foreign liquidity does not have a significant impact on long-term economic growth, although we can accept the idea that capital account liberalization in developing countries (Latin America included) plays a decisive role in real GDP growth. On the other hand, we have to consider the presence of heterogeneity across countries, expressed by different country size, degree of foreign liquidity, and degree of trade openness. As we 
surveyed in the second section of this paper, different studies have found a considerable link between international liquidity (financial opening) and growth as suggested by Edwards (2001) among others, or no link at all as pointed out by Rodriguez and Rodrik (2001).

A final word based on the analysis of Latin America economic performance over the last decades should emphasize that economies with a higher degree of financial and trade opening are not necessarily the ones with higher growth rates, but the ones who face a higher international liquidity may be more suitable to sustain a higher economic growth rate over time.

\section{References}

Anderson, T. W. \& Hsiao, C. (1982). Formulation and estimation of dynamic models using panel data. Journal of Econometrics, 18:47-82.

Arellano, M. \& Bond, S. (1991). Some tests of specification for panel data: Monte Carlo evidence and an application to employment equations. The Review of Economic Studies, 58(194).

Arteta, C., Eichengreen, B., \& Wyplosz, C. (2001). On the growth effects of capital account liberalization. NBER Working Papers, No. 8414.

Baldwin, R. E. (2003). Openness and growth: What's the empirical relationship? NBER Working Papers, No. 9578.

Barro, R. J., Mankiw, N. G., \& Sala-I-Martin, X. (1995). Capital mobility in neoclassical models of growth. American Economic Review, 85(1):103-115.

Bekaert, G., Harvey, C., \& Lundblad, C. (2001). Does financial liberalization spur growth? NBER Working Paper, No. 8245.

Blackburn, K. \& Hung, V. T. Y. (1998). A theory of growth, financial development and trade. Economica, 65(257):107-24.

DeGregorio, J., Edwards, S., \& Valdes, R. O. (2000). Controls on capital inflows: Do they work? NBER Working Paper, No. 7645 (April) (Cambridge, Massachusetts: National Bureau of Economic Research).

Edison, H., Levine, R., Ricci, L., \& Slok, T. (2002). International financial integration and economic growth. NBER Working Papers, No 9164. 
Edison, H. J. \& Reinhart, C. (2001). Stopping hot money. Journal of Development Economics, 66:533-53.

Edison, H. J. \& Warnock, F. E. (2001). A simple measure of the intensity of capital controls. IMF Working Paper 01/180.

Edwards, S. (2001). Capital mobility and economic performance: Are emerging economies different? No. 8076 (falta mais informação).

Eichengreen, B. (2001). Capital account liberalization: What do cross-country studies tell us? University of California, Berkeley, mimeo.

Eichengreen, B. \& Leblang, D. (2002). Capital account liberalization and growth: Was mr. mahathir right? NBER Working Papers, No. 9427.

Feldstein, M. \& Horioka, C. (1980). Domestic saving and international capital flows. The Economic Journal, 90(358):314-29.

Frees, E. W. (2003). Panel data analysis. Disponível em http://instruction.bus.wisc.Edu/Jfrees/Gb806.htm.

Greene, W. H. (1999). Econometric Analysis. Prentice Hall, fourth edition.

Grilli, V. \& Milesi-Ferretti, G. M. (1995). Economic effects and structural determinants of capital controls. IMF Staff Papers, 42(3):517-51.

Hansen, L. P. (1982). Large sample properties of generalized methods of moments. Econometrica, 50:1029-1054.

Hsiao, C. (1986). Analysis of panel data. Cambridge: UP. (Econometric Society Monographs, n. 11).

International Monetary Fund (2003a). Annual report on exchange arrangements and exchange restrictions. Various Issues.

International Monetary Fund (2003b). International financial statistics. CD-ROM.

Klein, M. (2003). Capital account openess and the varieties of growth experience. NBER Working Paper 9500.

Klein, M. \& Olivei, G. (1999). Capital account liberalization, financial depth, and economic growth. NBER Working Papers, No 7384. 
Kraay, A. (1998). In search of the macroeconomic effects of capital account liberalization. mimeo.

Levine, R., Loyaza, N., \& Beck, T. (1999). Financial intermediation and growth: Causality and causes. Working Paper Series 2059. World Bank: World Bank Policy Research, Washington, D.C.

Levine, R. \& Renelt, D. (1992). A sensitivity analysis of cross country growth regressions. American Economic Review, pages 942-63.

Levine, R. \& Zervos, S. (1998). Stock markets, banks, and economic growth. American Economic Review, 88:537-58.

McLean, B. \& Shrestha, S. (2002). International financial liberalization and economic growth. Research Discussion Papers, Reserve Bank of Australia.

Obstfeld, M. (1994). Risk-taking, global diversification and growth. American Economic Review, 84(5):1310-1329.

Quinn, D. (1997). The correlates of change in international financial regulation. American Political Science Review, 91(3):531-51.

Rodriguez, F. \& Rodrik, D. (2001). Trade policy and economic growth: A skeptic's guide to the cross-national evidence. In Bernanke, B. \& Rogoff, K. S., editors, NBER Macroeconomics Annual 2000. MIT Press, Cambridge, MA.

Rodrik, D. (1998). Who needs capital-account convertibility? Harvard University, mimeo.

Sachs, J. \& Warner, A. (1995). Economic reform and the process of global integration. Brookings Papers on Economic Activity, 1:1-118.

Sargan, J. D. (1958). The estimation of economic relationships using instrumental variables. Econometrica, 26:393-415.

Sargan, J. D. (1983). Identification and lack of identification. Econometrica, 51:1605-1633.

World Bank (2003). World development indicators. World Bank: Washington: DC. (http://www.wb.org). 


\section{Appendix A}

Table A.1

Overview of empirical studies on financial opening and growth

\begin{tabular}{|c|c|c|c|c|c|c|}
\hline $\begin{array}{l}\text { Author } \\
\text { (year) }\end{array}$ & $\begin{array}{l}\text { Countries (Pe- } \\
\text { riod) }\end{array}$ & $\begin{array}{l}\text { Measures } \\
\text { of Capital } \\
\text { Account Lib- } \\
\text { eralization }\end{array}$ & $\begin{array}{l}\text { Dependent } \\
\text { Variable }\end{array}$ & Other Variables & $\begin{array}{l}\text { Estimation } \\
\text { Technique } \\
\text { (Methodol- } \\
\text { ogy) }\end{array}$ & Main Results \\
\hline Klein (2003) & 85 (1976-1995) & $\begin{array}{l}\text { Share Aver- } \\
\text { age Quinn }\end{array}$ & $\begin{array}{l}\text { Change } \\
\text { in natural } \\
\text { log of real } \\
\text { per capita } \\
\text { income }\end{array}$ & $\begin{array}{l}\text { Log of real per } \\
\text { capita income in } \\
1976, \quad \text { secondary } \\
\text { school enrollment } \\
\text { rate, average rate of } \\
\text { I / GDP (1974-78), } \\
\text { population growth } \\
\text { rate (1976-95), } \\
\text { dummy for Africa }\end{array}$ & $\begin{array}{l}\text { OLS and } \\
\text { IV (In- } \\
\text { strumental } \\
\text { Variables) } \\
\text { (Cross } \\
\text { Section) }\end{array}$ & $\begin{array}{lr}\text { Inverted } & \text { U- } \\
\text { shaped relation- } \\
\text { ship } & \text { between } \\
\text { capital account } \\
\text { (KA) openness } \\
\text { and income per } \\
\text { capita. Middle } \\
\text { income countries } \\
\text { benefits from KA } \\
\text { openness while } \\
\text { rich or poor coun- } \\
\text { tries do not face } \\
\text { positive effects }\end{array}$ \\
\hline $\begin{array}{l}\text { Eichengreen } \\
\text { and Leblang } \\
(2002)\end{array}$ & $\begin{array}{lc}21 & (1880-1997) \\
47 & (1975-1995)\end{array}$ & Share & $\begin{array}{l}\text { Growth of } \\
\text { real per- } \\
\text { capita GDP }\end{array}$ & $\begin{array}{l}\text { Log of income per } \\
\text { capita relative to } \\
\text { the US, primary and } \\
\text { secondary school } \\
\text { enrollment, capital } \\
\text { control, govern- } \\
\text { ment consumption, } \\
\text { inflation, trade } \\
\text { openness, domestic } \\
\text { and international } \\
\text { crises. }\end{array}$ & $\begin{array}{l}\text { Dynamic } \\
\text { Panel }\end{array}$ & $\begin{array}{l}\text { Net effect of } \\
\text { capital controls } \\
\text { on growth is } \\
\text { positive in peri- } \\
\text { ods of financial } \\
\text { instability but } \\
\text { negative when in } \\
\text { the absence of } \\
\text { crises. Capital } \\
\text { account liberal- } \\
\text { ization is not a } \\
\text { panacea and its } \\
\text { benefits dominate } \\
\text { the costs when } \\
\text { the economies } \\
\text { have a robust } \\
\text { financial system }\end{array}$ \\
\hline $\begin{array}{l}\text { Edison et al. } \\
(2002)\end{array}$ & $57(1976-2000)$ & Share & $\begin{array}{lr}\text { Real } & \text { per } \\
\text { capita } & \text { GDP } \\
\text { growth } & \end{array}$ & 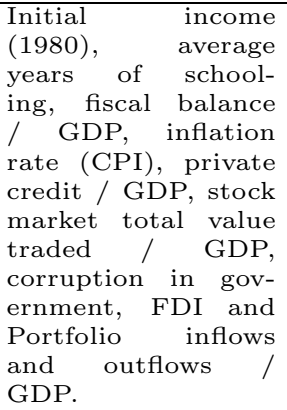 & $\begin{array}{l}\text { OLS (cross } \\
\text { section) } \\
2 \text { SLS IV } \\
\text { (cross sec- } \\
\text { tion) GMM } \\
\text { dynamic } \\
\text { panel }\end{array}$ & $\begin{array}{l}\text { International } \\
\text { financial inte- } \\
\text { gration does } \\
\text { not accelerate } \\
\text { economic growth }\end{array}$ \\
\hline $\begin{array}{l}\text { Edison et al. } \\
(2002)\end{array}$ & 89 (1976-1995) & $\begin{array}{l}\text { Share, } \\
\text { Quinn, } \\
\text { and Dates of } \\
\text { Stock Market } \\
\text { Liberaliza- } \\
\text { tion }\end{array}$ & $\begin{array}{lr}\text { Real } & \text { per } \\
\text { capita } & \text { GDP } \\
\text { growth } & \end{array}$ & $\begin{array}{lrr}\text { Log Real per capita } \\
\text { income; log } & \text { sec- } \\
\text { ondary } & \text { school } \\
\text { enrollment } & \text { rate; } \\
\text { average I / } & \text { GDP } \\
\text { ratio; population } & \text { growth rate; dummy } \\
\text { Africa. Instruments: } \\
\text { Government r con- } \\
\text { sumption / } & \text { GDP, } \\
\text { Imports / } & \text { GDP, } \\
\text { Dummy for Latin } \\
\text { America and East } \\
\text { Asia. }\end{array}$ & $\begin{array}{l}\text { OLS } \text { and } \\
\text { IV }\end{array}$ & $\begin{array}{l}\text { Mixed } \text { evidence } \\
\text { that that cap- } \\
\text { ital account } \\
\text { liberalization } \\
\text { promotes long- } \\
\text { term economic } \\
\text { growth. Find } \\
\text { some support for } \\
\text { a positive effect } \\
\text { of KA liberaliza- } \\
\text { tion on growth, } \\
\text { especially for } \\
\text { developing coun- } \\
\text { tries (East Asia) }\end{array}$ \\
\hline
\end{tabular}




\begin{tabular}{|c|c|c|c|c|c|c|}
\hline $\begin{array}{l}\text { Author } \\
\text { (year) }\end{array}$ & $\begin{array}{l}\text { Countries } \\
\text { (Period) }\end{array}$ & $\begin{array}{l}\text { Measures of } \\
\text { Capital } \\
\text { Account } \\
\text { Liberalization }\end{array}$ & $\begin{array}{l}\text { Dependent } \\
\text { Variable }\end{array}$ & $\begin{array}{l}\text { Other } \\
\text { Variables } \\
\text { (Methodology) }\end{array}$ & $\begin{array}{l}\text { Estimation } \\
\text { Technique }\end{array}$ & $\begin{array}{l}\text { Main } \\
\text { Results }\end{array}$ \\
\hline $\begin{array}{l}\text { McLean and } \\
\text { Shrestha } \\
(2002)\end{array}$ & $40(1976-1995)$ & $\begin{array}{l}\text { Capital } \\
\text { Flows }\end{array}$ & $\begin{array}{l}\text { Growth rate } \\
\text { in real GDP } \\
\text { per capita }\end{array}$ & 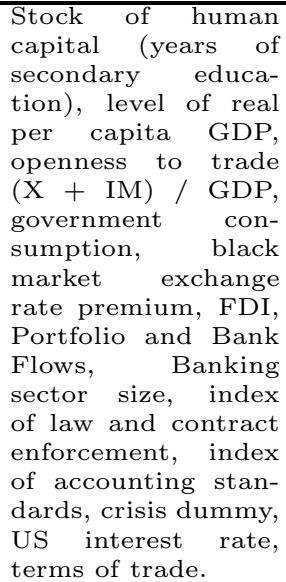 & $\begin{array}{l}\text { Panel (av- } \\
\text { erage over } \\
\text { five non- } \\
\text { overlapping } \\
\text { years) }\end{array}$ & $\begin{array}{l}\text { FDI and Portfolio } \\
\text { inflows improves } \\
\text { economic growth, } \\
\text { while bank in- } \\
\text { flows have a } \\
\text { negative effect. }\end{array}$ \\
\hline $\begin{array}{l}\text { Edwards } \\
(2001)\end{array}$ & $62(1980-1989)$ & Quinn Share & $\begin{array}{l}\text { Average real } \\
\text { GDP growth } \\
\text { Average } \\
\text { rate of To- } \\
\text { tal Factor } \\
\text { Productiv- } \\
\text { ity growth } \\
\text { during } 1980 \mathrm{~s}\end{array}$ & $\begin{array}{l}\text { Investment / GDP, } \\
\text { number of years of } \\
\text { schooling, and log of } \\
\text { real GDP per capita } \\
\text { in } 1965\end{array}$ & $\begin{array}{l}\text { WLS, } \\
\text { W2SLS, } \\
\text { SURE and } \\
\text { W3SLS } \\
\text { and IV } \\
\text { (Cross } \\
\text { Section) }\end{array}$ & $\begin{array}{l}\text { KA liberaliza- } \\
\text { tion significantly } \\
\text { raises } r \text { GDP } \\
\text { growth. Evidence } \\
\text { suggesting that } \\
\text { an open capital } \\
\text { account has a } \\
\text { positive effect } \\
\text { on long-term } \\
\text { growth only after } \\
\text { certain degree } \\
\text { of economic } \\
\text { development } \\
\text { (support the idea } \\
\text { of an optimal se- } \\
\text { quencing for KA } \\
\text { liberalization). }\end{array}$ \\
\hline $\begin{array}{l}\text { Arteta et al. } \\
(2001)\end{array}$ & $59(1980-1989)$ & $\begin{array}{l}\text { Quinn Sachs- } \\
\text { Warner Non } \\
\text { financial } \\
\text { Openness }\end{array}$ & $\begin{array}{lr}\text { Rate } & \text { of } \\
\text { growth of } \\
\text { real GDP per } \\
\text { capita }\end{array}$ & $\begin{array}{l}\text { Real investment } \\
\text { / GDP, average } \\
\text { years of schooling, } \\
\text { log of GDP per } \\
\text { capita, financial } \\
\text { depth, law and } \\
\text { order index, trade } \\
\text { openness dummy, } \\
\text { black market pre- } \\
\text { mium, distance } \\
\text { to the equator, } \\
\text { OECD membership } \\
\text { dummy, languave } \\
\text { variables, land- } \\
\text { locked nation } \\
\text { dummy, island } \\
\text { nation dummy. }\end{array}$ & $\begin{array}{l}\text { OLS (cross } \\
\text { section) } \\
\text { WLS and } \\
\text { ULS with } \\
\text { IV (cross } \\
\text { section) } \\
\text { Moving } \\
\text { Average } \\
\text { Panel Data }\end{array}$ & $\begin{array}{l}\text { Find indications } \\
\text { of a positive as- } \\
\text { sociation between } \\
\text { KA liberaliza- } \\
\text { tion and growth, } \\
\text { but the effect } \\
\text { changes with } \\
\text { time and how KA } \\
\text { liberalization is } \\
\text { measured. More } \\
\text { evidence of a cor- } \\
\text { relation between } \\
\text { KA liberalization } \\
\text { and growth when } \\
\text { including other } \\
\text { dimensions of } \\
\text { openness }\end{array}$ \\
\hline
\end{tabular}




\begin{tabular}{|c|c|c|c|c|c|c|}
\hline $\begin{array}{l}\text { Author } \\
\text { (year) }\end{array}$ & $\begin{array}{l}\text { Countries } \\
\text { (Period) }\end{array}$ & $\begin{array}{l}\text { Measures of } \\
\text { Capital } \\
\text { Account } \\
\text { Liberalization }\end{array}$ & $\begin{array}{l}\text { Dependent } \\
\text { Variable }\end{array}$ & $\begin{array}{l}\text { Other } \\
\text { Variables } \\
\text { (Methodology) }\end{array}$ & \begin{tabular}{|l} 
Estimation \\
Technique
\end{tabular} & $\begin{array}{l}\text { Main } \\
\text { Results }\end{array}$ \\
\hline $\begin{array}{l}\text { Bekaert et al. } \\
(2001)\end{array}$ & $95(1980-1997)$ & $\begin{array}{l}\text { Official } \\
\text { Dates of } \\
\text { Stock Market } \\
\text { Liberaliza- } \\
\text { tion }\end{array}$ & $\begin{array}{l}\text { Growth rates } \\
\text { in per capita } \\
\text { income }\end{array}$ & $\begin{array}{l}\text { I / GDP, secondary } \\
\text { school enrollment, } \\
\text { size of government } \\
\text { sector, C / GDP, } \\
\text { Trade / GDP, pop- } \\
\text { ulation growth, life } \\
\text { expectancy }\end{array}$ & Panel & $\begin{array}{l}\text { Stock market } \\
\text { liberalization } \\
\text { significantly } \\
\text { contributes to } \\
\text { growth, with } \\
\text { largest effects } \\
\text { shortly after } \\
\text { liberalization. } \\
\text { Equity market } \\
\text { liberalization, on } \\
\text { average, lead to a } \\
\text { one per cent in- } \\
\text { crease in annual } \\
\text { real economic } \\
\text { growth over a five } \\
\text { year period. I / } \\
\text { GDP increases } \\
\text { after the liber- } \\
\text { alization due to } \\
\text { foreign capital } \\
\text { inflows and a } \\
\text { worsening in the } \\
\text { trade balance. }\end{array}$ \\
\hline $\begin{array}{lr}\text { Klein } & \text { and } \\
\text { Olivei } & (1999)\end{array}$ & 67 (1976-1995) & Share & $\begin{array}{l}\text { Growth } \\
\text { in income } \\
\text { per capita; } \\
\text { Change in } \\
\text { Financial } \\
\text { Depth (FD) } \\
\text { as a function } \\
\text { of Share; Per } \\
\text { capita in- } \\
\text { come growth } \\
\text { as a function } \\
\text { of FD (and } \\
\text { initial FD). }\end{array}$ & $\begin{array}{l}\text { Mismanagement } \\
\text { (inflation and } 1+ \\
\text { black market ex- } \\
\text { change premium), X } \\
\text { + IM / GDP, liquid } \\
\text { liabilities / GDP, } \\
\text { domestic credit } \\
\text { / GDP, private } \\
\text { bank ratio, inflation } \\
\text { (CPI), black market } \\
\text { premium, I / GDP, } \\
\text { G / GDP }\end{array}$ & $\begin{array}{l}\text { IV (Cross } \\
\text { Section) }\end{array}$ & $\begin{array}{l}\text { Significant effect } \\
\text { of Share on fi- } \\
\text { nancial deepness } \\
\text { (FD), though } \\
\text { results seem to } \\
\text { be driven by } \\
\text { OECD countries } \\
\text { in sample. Sig- } \\
\text { nificant effect } \\
\text { of instrumented } \\
\text { values of FD and } \\
\text { FD on growth. }\end{array}$ \\
\hline $\begin{array}{l}\text { Levine, } \\
\text { Loayza and } \\
\text { Beck (1999) }\end{array}$ & $74(1960-1995)$ & $\begin{array}{l}\text { Liquid } \begin{array}{r}\text { lia- } \\
\text { bilities }\end{array} \text { of } \\
\text { the financial } \\
\text { system } \\
\text { GDP Assets } \\
\text { of deposit } \\
\text { money banks } \\
/ \text { assets } \\
\text { of deposit } \\
\text { money banks } \\
+\quad \text { central } \\
\text { bank as- } \\
\text { sets Credit } \\
\text { by deposit } \\
\text { money banks } \\
\text { and other } \\
\text { financial in- } \\
\text { stitutions to } \\
\text { the private } \\
\text { sector / GDP }\end{array}$ & $\begin{array}{l}\text { Real per } \\
\text { capita GDP }\end{array}$ & $\begin{array}{l}\text { Government size, } \\
\text { log of initial income } \\
\text { per capita, openness } \\
\text { to trade, inflation, } \\
\text { average years of } \\
\text { secondary school- } \\
\text { ing, black market } \\
\text { premium, liquid } \\
\text { liabilities, private } \\
\text { credit, dummy, } \\
\text { growth rate of terms } \\
\text { to trade, legal origin }\end{array}$ & $\begin{array}{l}\text { IV (cross } \\
\text { section) } \\
\text { and Panel } \\
\text { (GMM) }\end{array}$ & $\begin{array}{lr}\text { Financial } & \text { de- } \\
\text { velopment } & \text { is } \\
\text { positively } & \text { as- } \\
\text { sociated } & \text { with } \\
\text { economic growth. }\end{array}$ \\
\hline
\end{tabular}




\begin{tabular}{|c|c|c|c|c|c|c|}
\hline $\begin{array}{l}\text { Author } \\
\text { (year) }\end{array}$ & $\begin{array}{l}\text { Countries } \\
\text { (Period) }\end{array}$ & $\begin{array}{l}\text { Measures of } \\
\text { Capital } \\
\text { Account } \\
\text { Liberalization }\end{array}$ & $\begin{array}{l}\text { Dependent } \\
\text { Variable }\end{array}$ & $\begin{array}{l}\text { Other } \\
\text { Variables } \\
\text { (Methodology) }\end{array}$ & $\begin{array}{l}\text { Estimation } \\
\text { Technique }\end{array}$ & $\begin{array}{l}\text { Main } \\
\text { Results }\end{array}$ \\
\hline $\begin{array}{l}\text { Rodrik } \\
\text { (1998) }\end{array}$ & $100(1973-1996)$ & Share & $\begin{array}{l}\text { Growth in } \\
\text { per capita } \\
\text { GDP }\end{array}$ & $\begin{array}{l}\text { I / GDP, Infla- } \\
\text { tion, Initial per } \\
\text { capita GDP, initial } \\
\text { secondary enroll- } \\
\text { ment rate, index of } \\
\text { quality of govern- } \\
\text { ment institutions, } \\
\text { regional dummies. }\end{array}$ & $\begin{array}{l}\text { OLS (Cross } \\
\text { Section) }\end{array}$ & $\begin{array}{l}\text { No evidience of } \\
\text { a significant ef- } \\
\text { fect of Share on } \\
\text { growth of income } \\
\text { per capita. Policy } \\
\text { choices with re- } \\
\text { spect to the cap- } \\
\text { ital account are } \\
\text { endogenous (de- } \\
\text { pend on economic } \\
\text { performance) }\end{array}$ \\
\hline Kraay (1998) & $117(1985-1997)$ & $\begin{array}{l}\text { Share; } \\
\text { Quinn; } \\
\text { Volume }\end{array}$ & $\begin{array}{l}\text { Growth in } \\
\text { per capita } \\
\text { GDP }\end{array}$ & $\begin{array}{l}\text { Investment (I), in- } \\
\text { flation }\end{array}$ & $\begin{array}{l}\text { OLS and } \\
\text { IV (Cross } \\
\text { Section) }\end{array}$ & $\begin{array}{l}\text { No effect of Share } \\
\text { or Quinn on } \\
\text { Growth. Coeffi- } \\
\text { cient on Volume } \\
\text { significant and } \\
\text { positive. }\end{array}$ \\
\hline Quinn (1997) & $58(1960-1989)$ & Quinn & $\begin{array}{l}\text { Growth in } \\
\text { per capita } \\
\text { income }\end{array}$ & $\begin{array}{l}\text { Initial } \text { GDP } \text { per } \\
\text { capita, I / GDP, } \\
\text { population growth } \\
\text { and recondary } \\
\text { school enrollment } \\
\text { rates. }\end{array}$ & $\begin{array}{l}\text { OLS (Cross } \\
\text { Section) }\end{array}$ & $\begin{array}{l}\text { KA liberaliza- } \\
\text { tion significantly } \\
\text { raises growth, } \\
\text { though no regres- } \\
\text { sion is presented } \\
\text { with both capital } \\
\text { controls and } \\
\text { openness. }\end{array}$ \\
\hline $\begin{array}{ll}\text { Grilli } & \text { and } \\
\text { Milesi- } & \\
\text { Ferretti } & \\
(1995) & \end{array}$ & 61 (1971-1994) & Share & $\begin{array}{l}\text { Growth in } \\
\text { per capita } \\
\text { income } \\
\text { for five- } \\
\text { years non- } \\
\text { overlapping } \\
\text { periods }\end{array}$ & $\begin{array}{l}\text { Central Bank Inde- } \\
\text { pendence, Political } \\
\text { Variables, Initial } \\
\text { Level of Income, } \\
\text { Lagged Share of } \\
\text { Budget Balance / } \\
\text { GDP, Degree of } \\
\text { Openness, Dummy } \\
\text { for Exchange Rate } \\
\text { Regime }\end{array}$ & Panel Data & $\begin{array}{l}\text { No Evidience of } \\
\text { a significant ef- } \\
\text { fect of Share on } \\
\text { growth of income } \\
\text { per capita }\end{array}$ \\
\hline
\end{tabular}

Share is proportion of years that IMF's AREAR shows open capital accounts (binary measure of restrictions on capital transactions) Quinn is Quinn's $0-4$ measure of capital account intensity Quinn is change in value of Quinn $0-4$ Volume is measure of volume of capital flows Sachs-Warner openness dummy, defined as a binary variable equal to one if none of the five following criteria holds: the country had average tariff rates higher than 40 per cent, its nontariff barriers covered on average more than 40 per cent of imports, it had a socialist economic system, the state had a monopoly of major exports, and its black market premium exceeded $20 \%$ 


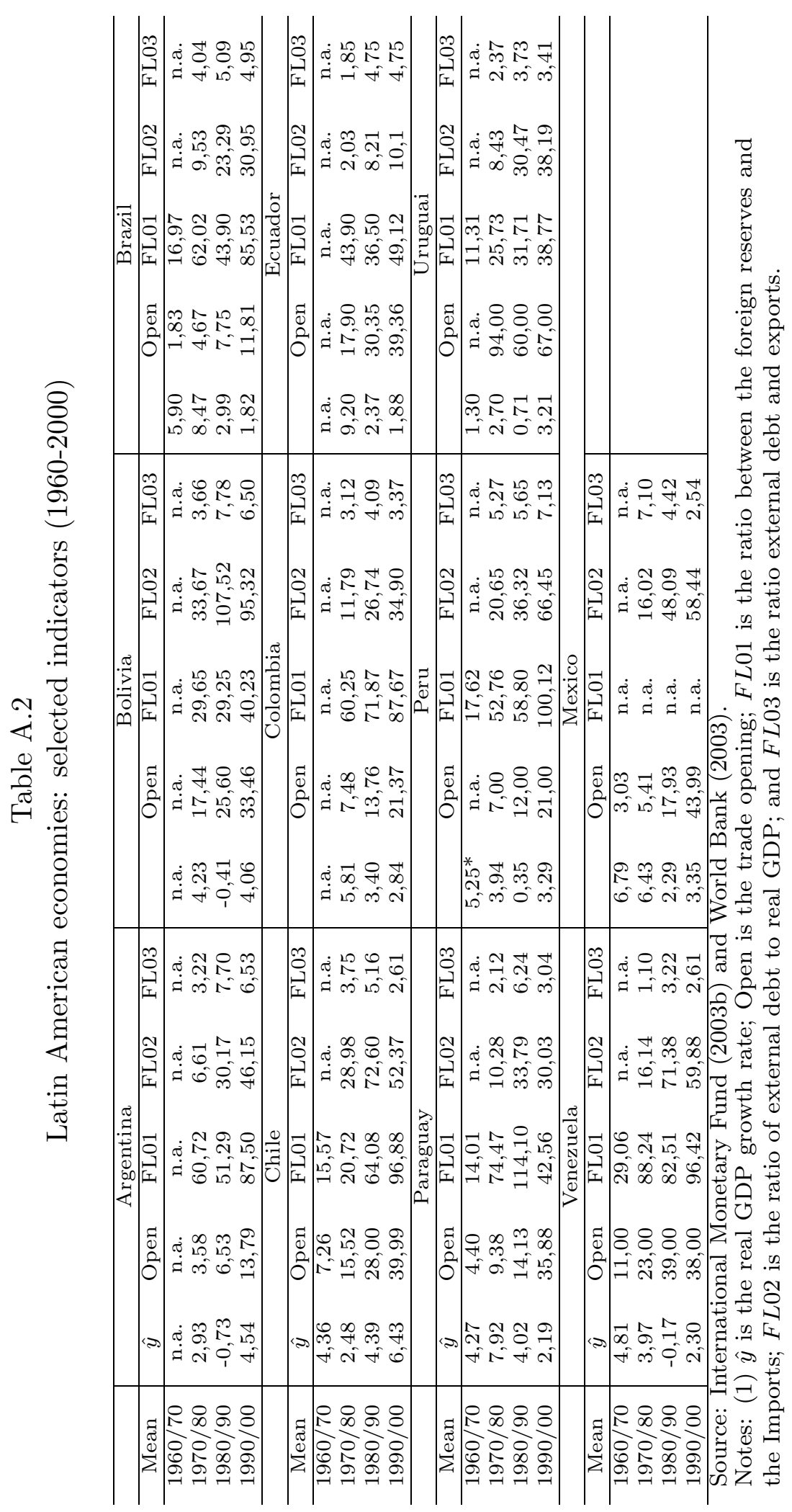


Table A.3

Correlation matrix

\begin{tabular}{|c|c|c|c|c|c|c|c|c|c|c|c|c|}
\hline & \multicolumn{6}{|c|}{ Original sample (1972-2000) } & \multicolumn{6}{|c|}{ Five years mean sample (1972-2000) } \\
\hline & Open & FL01 & FL02 & FL03 & $\mathrm{y}$ & $\hat{y}$ & Open & FL01 & FL02 & FL03 & $\mathrm{y}$ & $\hat{y}$ \\
\hline Open & 1 & & & & & & 1 & & & & & \\
\hline FL01 & 0,14 & 1 & & & & & 0,21 & 1 & & & & \\
\hline Fl02 & 0,1 & 0,08 & 1 & & & & 0,1 & 0,1 & 1 & & & \\
\hline FL03 & $-0,36$ & $-0,35$ & 0,17 & 1 & & & $-0,36$ & $-0,44$ & 0,17 & 1 & & \\
\hline $\mathrm{y}$ & 0,3 & $-0,25$ & $-0,09$ & 0,11 & 1 & & $-0,31$ & $-0,32$ & $-0,08$ & 0,13 & 1 & \\
\hline$\hat{y}$ & $-0,07$ & 0,003 & $-0,15$ & $-0,15$ & $-0,01$ & 1 & $-0,11$ & 0,04 & $-0,19$ & $-0,23$ & $-0,07$ & 1 \\
\hline
\end{tabular}

Table A.4

Basic statistic

\begin{tabular}{|c|c|c|c|c|c|c|}
\hline & \multicolumn{6}{|c|}{ Original sample (1972-2000) } \\
\hline & Open & FL01 & FL02 & FL03 & $\mathrm{y}(\mathrm{US} \$ \mathrm{mi})$ & $\hat{y}(\%$ per year $)$ \\
\hline Mean & 26,32 & 83,44 & 37,35 & 4,21 & $116.730,00$ & 3,27 \\
\hline $\mathrm{SD}$ & 20,85 & 51,63 & 32,19 & 2,27 & $167.260,00$ & 4,77 \\
\hline \multirow[t]{3}{*}{$\mathrm{CV}$} & 79,22 & 61,88 & 86,18 & 53,92 & 143,29 & 145,87 \\
\hline & \multicolumn{6}{|c|}{ Five years mean sample (1972-2000) } \\
\hline & Open & FL01 & FL02 & FL03 & $\mathrm{y}(\mathrm{US} \$ \mathrm{mi})$ & $\hat{y}(\%$ per year $)$ \\
\hline Mean & 25,94 & 83,76 & 36,23 & 4,17 & 115300 & 3,34 \\
\hline $\mathrm{SD}$ & 20,37 & 44,88 & 31,75 & 2,08 & 164240 & 3,16 \\
\hline $\mathrm{CV}$ & 78,53 & 53,58 & 87,63 & 49,88 & 142,45 & 94,61 \\
\hline
\end{tabular}

$\mathrm{SD}=$ Standard deviation

$\mathrm{CV}=$ Coefficient of variation measured by standard deviation relative to the mean. 


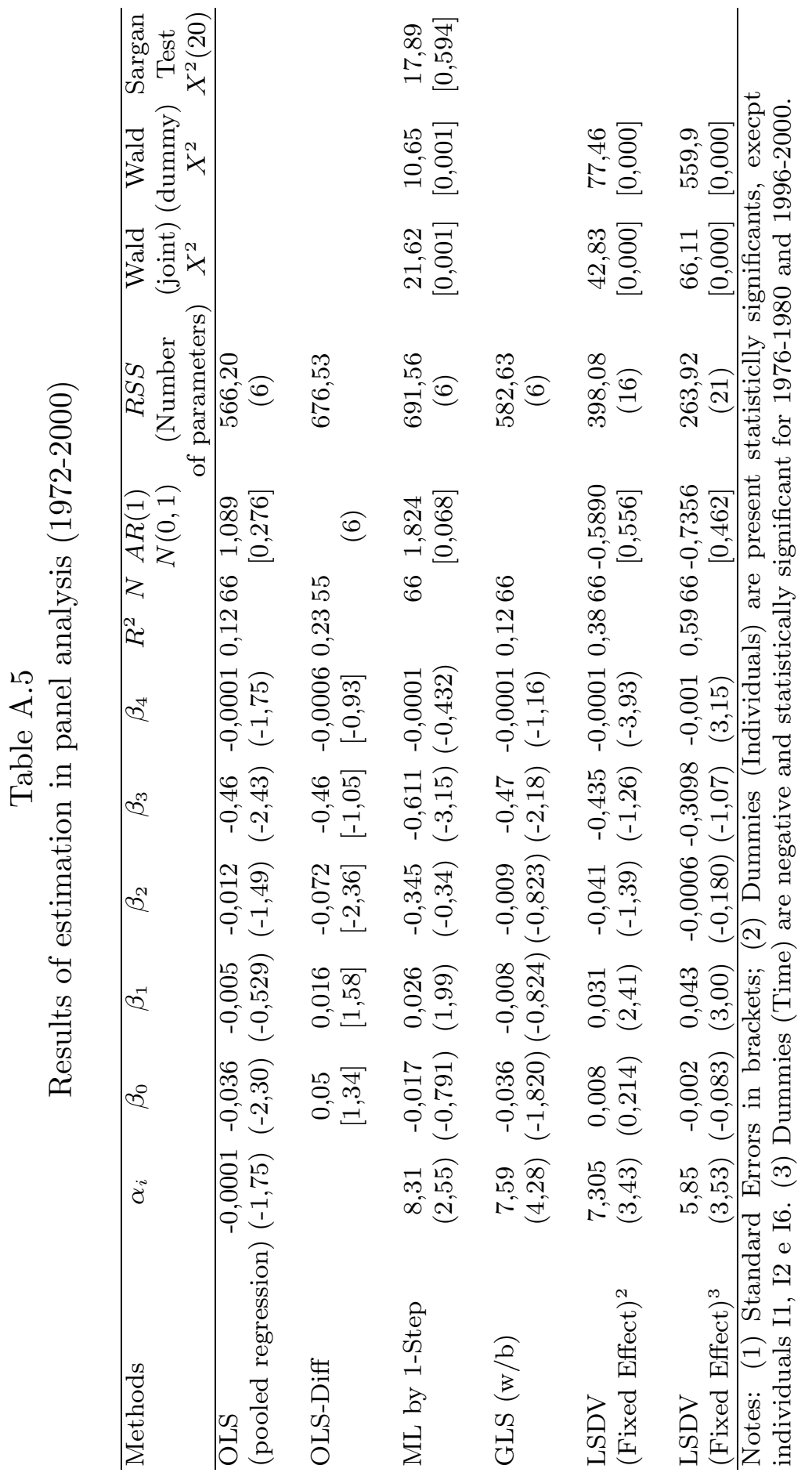

